\title{
AROMATHERAPY ADMINISTRATION AND PAIN SCALE 24 HOURS POST- CAESAREAN SECTION
}

Herlyssa $^{1}$, Theresia EVK $^{2}$

${ }^{1,2}$ Lecture Poltekkes Kemenkes Jakarta III

\section{INFORMASI ARTIKEL:}

\section{Riwayat Artikel:}

Tanggal diterima: September 2020

Tanggal di revisi: September 2020

Tanggal di Publikasi: Oktober 2020

Key Word: Orange essential oil aromatherapy, pain scale, post-SC

\begin{abstract}
A B S T R A C T
Aromatherapy can be used to reduce post-sectio caesaria (SC) pain. In this study, the aromatherapy used was orange essential oil. This quasi-experimental study used a pre and posttest design with control group. The sample of the study was 74 mothers with 24 hours post-SC. The treatment group was the mothers who were given orange essential oil aromatherapy ( 37 people), while the control group was those who were not given (37 people). Sampling technique used consecutive sampling. Data collection about the characteristics of the respondents was done using a questionnaire, while the measurement of pain was carried out using the Numerical Rating Scale (NRS) observation sheet. The analysis consisted of bivariate analysis with Wilcoxon test. There was a decrease in the pain scale in the treatment group after being given aromatherapy essential oil orange from $4.14 \pm 1.669$ to $2.59 \pm 1.334$ (p-value $=0.000)$. In the control group, the change was from $2.86 \pm 0.419$ to $2.78 \pm$ 0.479 (p-value $=0.373$ ). This meant that the treatment group showed higher reduced pain than the control group. Therefore, orange essential oil aromatherapy was effective in reducing pain scale 24 hours post-SC.
\end{abstract}

\section{INTRODUCTION}

Initially, aromatics using plants were part of herbal medicine. This treatment has been around for thousands of years and is not limited to one geographic area. The use of technology in the distillation of essential oils from aromatic plants forms the basis of contemporary 'aromatherapy'. [1] In fact, various non-pharmaceutical pain managements have been used for pain control. Aromatherapy, a method of treatment that uses fragrant extracts from plants which are generally through inhalation and/or massage, has been widely used as a pain reliever in labor, which is one of the most painful conditions that occur in humans during childbirth.[2]

Delivery with SC will cause pain which makes the patient uncomfortable. Nonpharmacological therapy in the form of aromatherapy is one of the efforts made to reduce post-SC pain. Several studies conducted in Indonesia reported that the average pain scale after giving aromatherapy to the control group was $4.65 \pm 1.10$ while the average pain scale after treatment, in the lavender oil aromatherapy group was $2.53 \pm$ 1.35.[3] Karningsih, Jehanara and Winancy (2015) also reported that the mean labor pain in the group given aromatherapy essential oil was slightly higher (mean $5.053 \pm 1,129$ ) than the group given lavender oil aromatherapy (mean $3.5 \pm$ 0.761).[4] Another study by Dwijayanti, et al, in 2014, reported that the pain scale in 32 post-sectio caesarean patients who were given lavender aromatherapy inhalation experienced a significant decrease compared to before being given treatment.[5] In addition, Olapour, et al, in 2013 also found that the addition of pain relief in the form of diclofenac suppositories in the placebo group was significantly higher than the group given lavender aromatherapy $(\mathrm{P}=0.008)$.[6] 
Based on the results of a preliminary study at the Tangerang District Hospital of 10 post-SC patients, it was found that $20 \%$ experienced severe pain and $80 \%$ experienced moderate pain. Based on the results of tracing medical records in the Hospital, pain management in post-SC patients when entering the inpatient room uses analgesics in the form of protofen suppositoria $3 \mathrm{x} /$ day. If after 24 hours there is still pain, the treatment continues with mefenamic acid $3 \times 500 \mathrm{mg}$ orally. This research objective was to determine the use of orange essential oil aromatherapy in reducing the pain scale of 24 hours post-SC in Tangerang District Hospital.

\section{METHOD}

This quasi-experimental study used a pre and posttest design with control group. The population in this study was all mothers 24 hours post-SC in Tangerang District Hospital. The sample of the study was 74 mothers with 24 hours post-SC. The treatment group was the mothers who were given orange essential oil aromatherapy (37 people), while the control group was those who were not given (37 people). Sampling technique used consecutive sampling. Data collection about the characteristics of the respondents was done using a questionnaire, while the measurement of pain was carried out using the Numerical Rating Scale (NRS) observation sheet.

This research was started by measuring the pain scale 24 hours post-SC. After that, the treatment group was given through tissue media that had been dripped with 3 drops, and then inhaled the fragrance for 5 minutes at a distance of $10 \mathrm{~cm}$. Aromatherapy was only given once at 24 hours post SC. Meanwhile, the control group was not given aromatherapy essential oil with orange aroma. After 30 minutes of giving the aromatherapy, the treatment and control groups were continuously observed and assessed for their pain scale. Variable data was tested for normality and homogeneity test. The analysis consisted of bivariate analysis with Wilcoxon test. This research had gone through an ethical review process and had been approved for research.

\section{RESULT AND DISCUSSION}

Based on the test results using the Wilcoxon test in Table 1, it was known that the orange essential oil aromatherapy group obtained a pvalue of $0.000(p<0.05)$. From the results of this test, it was evident that the provision of the aromatherapy was proven to significantly reduce pain 24 hours post-SC. In contrast, in the control group, the p-value was 0.373 (p> $0.05)$. This test shows that in the control group there was no significant reduction in post-SC pain.

\section{Table 1}

Mean difference in pain scale 24 hours postSC before and after treatment in both groups

\begin{tabular}{|c|c|c|c|c|}
\hline Group & Mean & SD & $\mathrm{SE}$ & $\mathrm{P}$ value \\
\hline Treatment before & 4.14 & 1.669 & 0.274 & 0.000 \\
\hline after & 2.59 & 0.069 & 0.069 & \\
\hline Control before & 2.86 & 0.419 & 0.02 & 0.373 \\
\hline after & 2.78 & 0.479 & 0.09 & \\
\hline
\end{tabular}

The results showed that the mean pain scale of 24 hours post-SC in the treatment group and the control group before the intervention had a different pain scale. The pain scale in the treatment group was higher than in the control group. However, after being given aromatherapy, in the treatment group there was a significant decrease in the average pain scale of 1.55 , while in the control group there was a decrease in the average pain scale of only 0.08 . This indicated that aromatherapy could reduce pain 24 hours post-SC. This was 


\section{The Southeast Asian Journal of Midwifery Vol. 6, No.2, Oktober 2020, p: 63-67

in accordance with Hadi and Hamid (2011),[7] who reported that the pain scale was lower in the group using aromatherapy.

This study wass also in accordance with Dwijayanti, et al, (2014) who reported that the pain scale in 32 post-SC patients who were given lavender aromatherapy inhalation experienced a significant decrease compared to before being given the treatment. Likewise, another study by Olapour, et al, (2013), which resulted in the addition of anti-pain in the form of diclofenac suppositories in the placebo group was significantly higher than the group given lavender aromatherapy $(p=0.008)$. However, in this current study, there was no additional pain medication given because it was proven that the aromatherapy itself was effective in reducing post-SC pain. In addition, the results of this study were not in accordance with Tarsika (2008) who explained that aromatherapy had no effect on the level of pain in childbirth mothers.[8]

Labor pain, including post-CS, can vary widely in terms of its perceived intensity and location. Labor pain relief methods are divided into non-pharmacological (psychoprophylaxis, hypnotism, acupuncture, touch healing therapy, relaxation exercises, massage therapy, music therapy, etc.)[9] and pharmacological (systemic drugs, inhalation anesthetics, general anesthesia, regional anesthesia) method.[10] In terms of aromatherapy as an effective way of managing pain and the psychological impact of interventions, one way it works is that the aroma of this oil is sent as a signal to the olfactory bulb which has close anatomical bonds with the limbic system affecting the endocrine and autonomic nerves. Inhalation of essential oils has enhanced olfactory aromatherapy, wherein simple inhalation has resulted in increased emotional health, calm, relaxation or rejuvenation of the human body. Stress release is welded by pleasant aromas which open up odor memories. Aromatherapy offers relaxation and can promote sleep. It also increases the mother's ability to cope with the pain of labor. [11]

Aromatherapy has been widely used as an alternative treatment to treat health conditions starting from stress, insomnia, depression, and others.[12] Naturally, it's getting easier and easier to find aromatherapy products that claim to be beneficial to the body. Because aromatherapy is a way of utilizing natural oils extracted from plants with the aim of improving physical and emotional health, essential oils made from various medicinal plants, flowers, herbs, roots, fruits, and trees that grow around the world are very beneficial for cultivation. According to a number of studies, several types of essential oils have been shown to have a positive effect on improving one's physical and emotional condition.[13]

Aromatherapy is trusted for more than thousands of years in various cultures around the world. It is believed that aromatherapy is a natural healer that can function as antibacterial, anti-inflammatory, as well as providing anti-pain effects. Essential oils can be used for aromatherapy in a variety of ways: using a diffuser by converting essential oils into fragrant steam, inhaling oil through the nose directly through clothes or from a bottle, doing massage therapy using essential oils, soaking in water mixed with essential oils, and apply essential oils directly on your skin.

The benefits of aromatherapy for the body and mind include, among other things, relaxation. Many studies have shown that essential oils used in aromatherapy, such as lavender and chamomile oil, can calm the mind when experiencing anxiety or excessive stress. The scent of lavender is believed to provide a relaxing effect and control the sympathetic 
nervous system, which is the nervous system responsible for the fight or flight stress response and its physical symptoms, such as sweaty hands or a racing heart. The second is to improve sleep quality. Since aromatherapy oils help people to reduce stress, it is believed that aromatherapy also helps one sleep better. A person with insomnia, anxiety, or restless leg syndrome and frequent itching at night can use aromatherapy to help sleep. The essential oil used in aromatherapy can be lavender oil. Try turning on the diffuser about an hour before you go to bed with lavender oil or any other oil you prefer.

The third is treating respiratory problems. Some aromatherapy oils have antiseptics that can help clean the air of bacteria, germs, and mold. These organisms are known to interfere with breathing, such as congestion, coughing, or sneezing. Tea tree oil or tea tree oil is considered to have antiseptic and antimicrobial properties while eucalyptus oil is thought to soothe breathing during colds. Then, the next benefit is to relieve pain and inflammation. To relieve pain or tense muscles, joint pain, inflamed tissue, or headaches, you can use the benefits of aromatherapy to reduce these complaints. Commonly used aromatherapy oils are ginger, turmeric, and orange to relieve joint pain. Then for headaches you can use the aroma of mint leaves, spearmint, and rosemary.

For pregnant and maternity women, the benefits of aromatherapy are for digestion and reduce nausea. Aromatherapy oils such as ginger, turmeric, grape, mint leaves, lemon, chamomile, and eucalyptus can help treat acid reflux, nausea, morning sickness (nausea during pregnancy), or stomach cramps during PMS. Turmeric and ginger essential oils are widely used in Asian countries as traditional medicine and food ingredients, due to their stomach-protecting properties. Both of these oils are high in antioxidants, which are believed to reduce necrosis, erosion, and bleeding in the stomach wall which significantly reduces abdominal pain. The next benefit is shown in this study, namely as a post-SC pain reliever. Therefore, the development of aromatherapy for health benefits is necessary to always be developed.

\section{CONCLUSION}

There was a significant mean difference in the pain scale 24 hours post-SC after being given orange essential oil aromatherapy to the treatment group. The aromatherapy was proven to reduce pain scale 24 hours post-SC.

\section{REFERENCE}

Buckle, J. (2015). The Evolution of Aromatherapy. Clinical Aromatherapy, 214. doi:10.1016/b978-0-7020-5440-2.00001-2

Chen, S.-F., Wang, C.-H., Chan, P.-T., Chiang, H.-W., Hu, T.-M., Tam, K.-W., \& Loh, E.-W. (2018). Labor pain control by aromatherapy: A meta-analysis of randomized controlled trials. Women and Birth. doi:10.1016/j.wombi.2018.09.010

Herlyssa, Jehanara dan Elly. 2018. Aromaterapi Lavender Essensial Oil Berpengaruh Dominan terhadap Skala Nyeri 24 Jam Post Seksio Sesaria. Jurnal Kesehatan Volume 9, Nomor 2, Agustus, 2018. http://ejurnal.poltekkes-tjk.ac.id/index.php/JK :192-198.

Karningsih, Jehanara dan Winancy.2015. Pengaruh aromaterapi Essensial Oil dan aromaterapi minyak lavender terhadap nyeri persalinan. Jakarta: Poltekkes Kemenkes Jakarta III.

Dwijayanti, Wening, Sumatrini Sri, Arianti Ida. 2014. Efek aroma terapi lvender inhalasi terhadap skala nyeri paska Sectio Caesarea. Med Host. Vol.2 (2): 120-125 
Olapour A, Behaeen K, Akhondzadeh R, Soltani F, al Sadat Raavi. 2013. The Effect of Inhalation of Aromatheraphy Blend Containing Lavender Essential Oil on Cesarean Postoperative Pain. Anesth pain. 3 (1):203-7.

Hadi, N., Hanid, A.A,. 2011. Lavender essence for post-cesarean pain. Pak J Biol Sci.14(11):664-7

Tarsika. (2008). Efektifitas Relaksasi Aromaterapi Terhadap Tingkat Nyeri Kala I Fase Aktif Pada Ibu Melahirkan Di RSIA Sakina Idaman Sleman Yogyakarta. Karya Tulis Ilmiah. Jogyakarta: Fakultas kedokteran Universitas Muhammadiyah Jogyakarta.

Leslie, A., \& Marlow, N. (2006). Nonpharmacological pain relief. Seminars in Fetal and Neonatal Medicine, 11(4), 246250. doi:10.1016/j.siny.2006.02.005

Mathew, E., Kim, E., \& Zempsky, W. (2016). Pharmacologic Treatment of Pain. Seminars in Pediatric Neurology, 23(3), 209 219. doi:10.1016/j.spen.2016.10.004

Yazdkhasti, M., \& Pirak, A. (2016). The effect of aromatherapy with lavender essence on severity of labor pain and duration of labor in primiparous women. Complementary Therapies in Clinical Practice, 25, 81-86. doi:10.1016/j.ctcp.2016.08.008

Ali, B., Al-Wabel, N. A., Shams, S., Ahamad, A., Khan, S. A., \& Anwar, F. (2015). Essential oils used in aromatherapy: A systemic review. Asian Pacific Journal of Tropical Biomedicine, 5(8), 601-611. doi:10.1016/j.apjtb.2015.05.007

Ahmad, R., Naqvi, A. A., Al-Bukhaytan, H. M., Al-Nasser, A. H., \& Baqer Al-Ebrahim, A. H. (2019). Evaluation of aromatherapy with lavender oil on academic stress: A randomized placebo controlled clinical trial. Contemporary Clinical Trials Communications, 14, 100346. doi:10.1016/j.conctc.2019.100346 